\title{
Detection of Rickettsia raoultii in Dermacentor reticulatus and Haemaphysalis inermis ticks in Slovakia
}

\author{
Basma Ouarti ${ }^{1,2}$ - Basma El Hamzaoui ${ }^{1,2}$ Michal Stanko ${ }^{3}$ Maureen Laroche ${ }^{1,2}$. Oleg Mediannikov ${ }^{1,2}$. \\ Philippe Parola ${ }^{1,2} \cdot$ Zuzana Sekeyová $^{4}$
}

Received: 8 March 2021 / Accepted: 14 May 2021 / Published online: 28 June 2021

(C) The Author(s) 2021

\begin{abstract}
Ticks are vector arthropods responsible for the transmission of several pathogenic agents that affect both human and animal health worldwide. In this study our objective was to analyse, using molecular tools, the bacterial community of Dermacentor reticulatus and Haemaphysalis inermis ticks collected in south-eastern Slovakia. Using real-time PCR, we identified the presence of Rickettsia spp. DNA at levels of 14/59 (23.72\%) and 29/173 (16.76\%) in D. reticulatus and H. inermis, respectively. In addition, using standard PCR and sequencing, we identified the presence of Rickettsia raoultii DNA in 13 ticks belonging to the two investigated species. Rickettsia raoultii blast results revealed an average identification percentage of $99.62 \%$. Following the results of this molecular study there is a possibility that $D$. reticulatus and H. inermis play a potential role in the transmission of $R$. raoultii. To prove the possibility of validity of this hypothesis, we suggest performing experimental models in future studies. Our results can serve as preliminary data for future transmission models.
\end{abstract}

Keywords Ticks $\cdot$ Dermacentor reticulatus $\cdot$ Haemaphysalis inermis $\cdot$ Slovakia

\section{Introduction}

Bacteria belonging to the genus Rickettsia are known as causative agents of various vector-borne zoonotic diseases. They are responsible for mild to severe diseases in humans (Parola et al. 2013; Eldin and Parola 2018).

The diversity of pathogens in ecosystems also depends on the species diversity of vectors and hosts and the diversity of

\section{Highlights}

- Dermacentor reticulatus and Haemaphysalis inermis ticks collected in south-eastern Slovakia are infected by Rickettsia raoultii.

- These preliminary data could be used in a future transmission model.

Philippe Parola

philippe.parola@univ-amu.fr

1 Aix Marseille Univ, IRD, AP-HM, SSA, VITROME, Marseille, France

2 IHU-Méditerranée Infection, Marseille, France

3 Institute of Parasitology, Slovak Academy of Sciences, Hlinkova 3, 04001 Košice, Slovak Republic

4 Biomedical Research Centre, Institute of Virology, Slovak Academy of Sciences, Dúbravská cesta 9, 84505 Bratislava, Slovak Republic habitats (de la Fuente et al. 2008). Many ticks in Europe, including Dermacentor reticulatus Fabricius, 1794 are known to act as carriers, reservoirs and/or vectors of different pathogenic Rickettsia species e.g., Rickettsia slovaca (Sekeyová et al. 1998; Garcia-Vozmediano et al. 2020) and Rickettsia raoultii (Boldiš et al. 2008; Földvári et al. 2013).

Revising the role of another tick species, Haemaphysalis inermis Birula, 1895 in the spread of rickettsiae continues to be challenging as few data have been previously published (Portillo et al. 2008; Špitalská et al. 2018). In a study carried out in Hungary, the authors detected the presence of $R$. helvetica in $H$. inermis and suggested that this tick species could be a potential vector of this pathogen (Hornok et al. 2010).

Recent epidemiological studies of Rickettsia in Slovakia were completed in suburban, natural and rural habitats (Minichová et al. 2017), or in an urban temperate forest (Chvostáč et al. 2018) in the western part of the country. A dry forest-steppe biotope is rarely referenced in literature except, in the past century, by Řeháček et al. (1976a, b). The authors indicated that: "The biotopes of the spotted fever group rickettsiae occurring in east Slovakia-namely, cultivated and meadow steppes with sparse forests-share some of the characteristics of the biotopes of Rickettsia sibirica. Thus, besides the new species of spotted fever group rickettsiae, 
the circulation of $R$. sibirica and perhaps of Rickettsia conorii in east Slovakia should not be excluded". However, none of them were ever confirmed in south-eastern Slovakia afterwards ( ̌̌eháček et al. 1976a, b).

Our objective was to investigate the possibility of detecting rickettsiae in $D$. reticulatus and $H$. inermis, two relatively abundant tick species in the steppe habitats of south-eastern Slovakia.

\section{Materials and methods}

\section{Tick collection and sampling site}

The tick collection was carried out on October 23, 2015 by flagging grass and shrubs using a white cotton flag passed over the vegetation at the level of three microhabitats (forest, ecotone and meadow) along a line of $100 \mathrm{~m}$ in the vegetation of the protected zone of Slovak Karst National Park in south-eastern Slovakia (Central Europe) near the village of Hrhov (200-220 m above sea level, $48^{\circ} 34.899 \mathrm{~N}, 20^{\circ} 46.743 \mathrm{E}$ ) (Fig. 1).

\section{DNA extraction and molecular detection of bacteria in ticks using real time PCR}

Half of the tick body without legs was selected for DNA extraction using EZ1 DNA tissue kit (Qiagen, Hilden, Germany) following a protocol previously elaborated in our laboratory (Diarra et al. 2017).

After extraction, the DNA of each sample was screened with the CFX96 real-time PCR (Bio -Rad, Marnes-laCoquette, France) and the LightCyclerR 480 Probes Master
Mix (Roche Diagnostics, Indianapolis, USA) for the presence of the following bacterial microorganisms (Rickettsia spp., Bartonella spp., Borrelia spp., Coxiella burnetii and Anaplasma spp.) using specific primers and probes listed in Diarra et al. (2020) and Ouarti et al. (2020).

The qPCR reaction mixture for each plate has been used according to the manufacturer's protocol. Negative controls were used in each qPCR and consisted of DNA extracted from uninfected Rhipicephalus sanguineus ticks from the laboratory colony of IHU - VITROME (Marseille, France). Positive controls included DNA extracted from a dilution of cultured strains of Borrelia crocidurae, Bartonella henselae, Rickettsia montanensis, Ehrlichia canis and Coxiella burnetii (Socolovschi et al. 2012b; Aouadi et al. 2017). Results were deemed positive if the cycle threshold $(\mathrm{Ct})$ value obtained by CFX96 was lower than $\leq 35$ (Ouarti et al. 2020).

\section{Bacterial species identification using sequencing}

All ticks tested positive for Anaplasma spp., Borrelia spp. and Rickettsia spp. in qPCR were subjected to amplification using standard PCR prior to sequencing for identification of the bacterial species (Dahmani et al. 2015b; Diarra et al. 2017). In standard PCR the primers used to amplify the ompA gene were (f-70 and r-701). For the sequencing we used the following primers (f-70, $\mathrm{f}-180$ and $\mathrm{r}-701)$ which amplify (629 to $632 \mathrm{bp}$ ) of protein A (Table 1) (Socolovschi et al. 2012a).

Primers targeting the Anaplasmataceae 23S, Borrelia 16S rRNA and Rickettsia ompA genes (Table 1), were used as described previously (Socolovschi et al. 2012a; Dahmani et al. 2015a; Ouarti et al. 2020).
Fig. 1 Geographical position of the tick collection locality in the south-eastern region of Slovakia

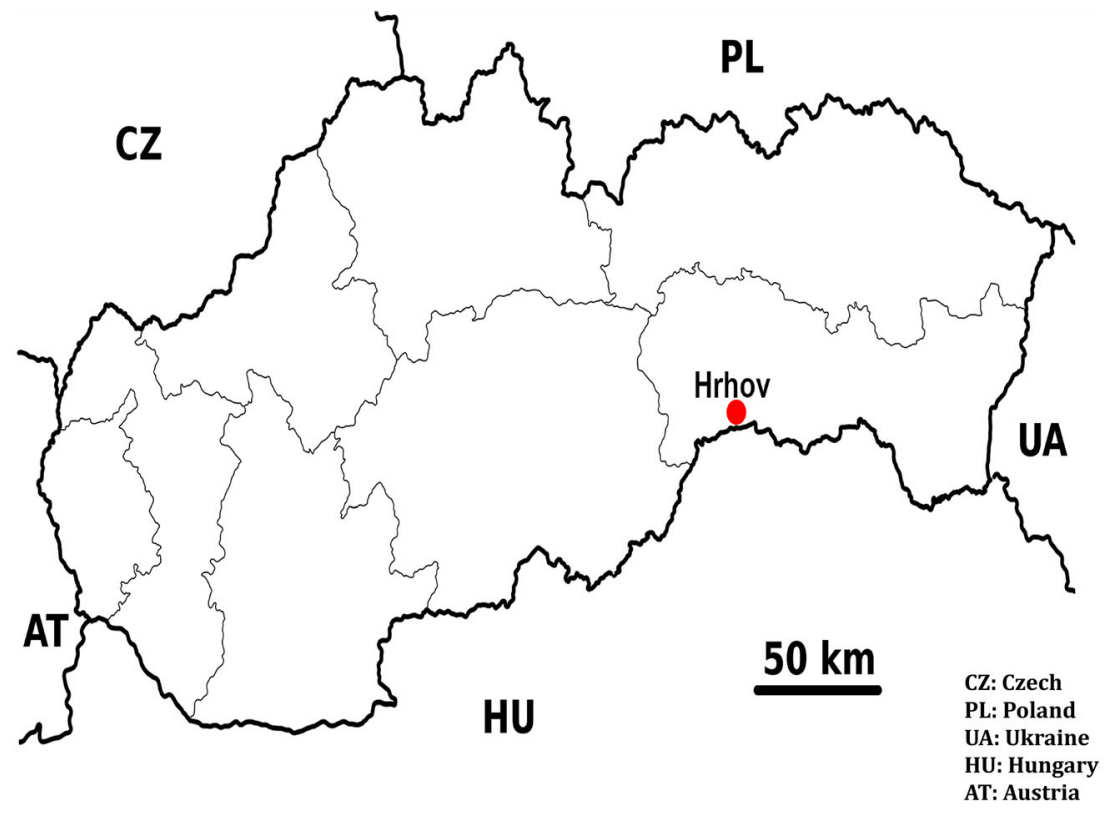


Table 1 Standard PCR primers used for the detection of microorganisms in ticks

\begin{tabular}{|c|c|c|c|}
\hline Bacterial species & $\begin{array}{l}\text { Targeted } \\
\text { sequences }\end{array}$ & Primers $\left(5^{\prime}-3^{\prime}\right)$ & Reference \\
\hline Anaplasmataceae & $23 S$ rRNA & f_ATAAGCTGCGGGGAATTGTC & (Dahmani et al. 2015a) \\
\hline Rickettsia spp. & ompA & $\begin{array}{l}\text { r_TGCAAAAGGTACGCTGTCAC } \\
\text { f_70_ATGGCGAATATTTCTCCAAA } \\
\text { A } \\
\text { r_701_GTTCCGTTAATGGC } \\
\text { AGCATCT } \\
\text { f_180_GCAGCGATAATGCT } \\
\text { GAGTA }\end{array}$ & $\begin{array}{l}\text { (Socolovschi et al. } \\
\text { 2012a) }\end{array}$ \\
\hline Borrelia spp. & $16 S$ rRNA & $\begin{array}{l}\text { f_GCTGGCAGTGCGTCTTAAGC } \\
\text { r_GCTTCGGGTATCCTCAACTC }\end{array}$ & $\begin{array}{l}\text { (Socolovschi et al. } \\
\text { 2012a) }\end{array}$ \\
\hline
\end{tabular}

The purified DNA products were sequenced using a Big Dye Terminator kit and a genetic analyzer ABI PRISM 3130 (Applied BioSystems, Courtaboeuf, France). The sequences obtained were analyzed with the software ChromasPro, version 1.34 (Technelysium Pty, Ltd., Tewantin, Queensland, Australie) in order to compare them to the GenBank database using BLAST (http: //blast.ncbi.nlm. Nih.gov/Blast.cgi) (Diarra et al. 2020).

\section{Results}

A total of 232 adult ticks (63 H. inermis males and $110 \mathrm{fe}-$ males, 31 D. reticulatus males and 28 females) were collected from vegetation in the protected zone of the Slovak Karst National Park. The proportion of ticks examined are detailed in (Table 2).

Using qPCR, 14/59 (23.72\%) D. reticulatus ticks tested positive for Rickettsia spp., 2/173 (1.15\%) H. inermis ticks tested positive for Anaplasmataceae bacteria, 1/173 (0.57\%) for Borrelia spp., and 29/173 (16.76\%) for Rickettsia spp.

The 43 ticks positive for Rickettsia in qPCR were then subjected to standard PCR amplification.

A total of $13 / 43(30.23 \%)$ ticks were successfully sequenced. BLAST analysis of these 13 sequences obtained showed an identity percentage ranging from 97.98 to $100 \%$ with the $R$. raoultii sequence. Details are given in Table 3. No Borrelia spp. or Anaplasmataceae sequences could be amplified.

\section{Discussion}

The investigated locality (Slovak karst near the village of Hrhov) is specific and unique due to the joint occurrence of seven tick species, Ixodes ricinus (Linnaeus, 1758), I. trianguliceps Birula, 1895, I. frontalis (Panzer, 1795), Dermacentor marginatus Sulzer, 1776, D. reticulatus, Haemaphysalis concinna C. L. Koch, 1844 and H. inermis (Černý 1972; Nosek 1972; Bona and Stanko 2013; Heglasová et al. 2020), which is an exceptional phenomenon in the conditions of Central Europe. Haemaphysalis punctata Canestrini \& Fanzago, 1878 which was the dominant species in tick communities in the area of Slovak karst in the last century, has not been confirmed there in recent decades. The high concentration of potential vectors (seven tick species) and hosts (cattle, free-living ungulates, several species of rodents and shrews) in the studied locality makes the Slovak karst a unique model for studying the circulation of several species of pathogens in their natural habitat (Nosek 1971; Heglasová et al. 2020). Uniqueness of the site (hereby presented) is from the point of view of the common occurrence of several species of ticks (see above). In terms of uniqueness or differentiation of pathogens in ticks compared to other sites, confirmation of a variety of bacteria in Haemaphysalis spp. which live on a common site with both species the genus Dermacentor is exclusive. In Slovakia, the presence of D. reticulatus has been identified along the rivers in southwestern and south-eastern Slovakia (Nosek 1972). Ticks of the genus Haemaphysalis ( $H$. inermis, $H$. concinna, H. punctata) are known to have a more focal distribution (Černý 1972; Nosek 1973).

Table 2 The proportion of ticks examined according to microhabitats (forest: ecotone: meadow)

\begin{tabular}{llll}
\hline Species of ticks & Forest & Ecotone & Meadow \\
\hline Dermacentor reticulatus & $2(3.4 \%)$ & $20(33.9 \%)$ & $37(62.7 \%)$ \\
Haemaphysalis inermis & $27(15.61 \%)$ & $121(69.94 \%)$ & $25(14.45 \%)$ \\
\hline
\end{tabular}


Table 3 BLAST analysis of Rickettsia obtained from tested ticks

\begin{tabular}{|c|c|c|c|c|}
\hline Ticks species & $\begin{array}{l}\text { Query cover } \\
(\%)\end{array}$ & $\begin{array}{l}\text { Percent identity } \\
(\%)\end{array}$ & $\begin{array}{l}\text { Accession } \\
\text { number }\end{array}$ & $\begin{array}{l}\text { Molecular identification by } \\
\text { BLAST }\end{array}$ \\
\hline $\begin{array}{l}\text { Dermacentor } \\
\text { reticulatus }\end{array}$ & 100 & 97.98 & HM161789.1 & Rickettsia raoultii \\
\hline $\begin{array}{r}\text { Dermacentor } \\
\text { reticulatus }\end{array}$ & 100 & 100 & KX506737.1 & Rickettsia raoultii \\
\hline $\begin{array}{r}\text { Dermacentor } \\
\text { reticulatus }\end{array}$ & 100 & 99.84 & HM161789.1 & Rickettsia raoultii \\
\hline $\begin{array}{r}\text { Dermacentor } \\
\text { reticulatus }\end{array}$ & 100 & 100 & KX506737.1 & Rickettsia raoultii \\
\hline $\begin{array}{l}\text { Dermacentor } \\
\text { reticulatus }\end{array}$ & 100 & 99.68 & HM161792.1 & Rickettsia raoultii \\
\hline $\begin{array}{l}\text { Haemaphysalis } \\
\text { inermis }\end{array}$ & 99 & 99.84 & СР003426.1 & Rickettsia raoultii \\
\hline $\begin{array}{l}\text { Haemaphysalis } \\
\quad \text { inermis }\end{array}$ & 99 & 98.63 & СР003426.1 & Rickettsia raoultii \\
\hline $\begin{array}{l}\text { Haemaphysalis } \\
\quad \text { inermis }\end{array}$ & 100 & 99.41 & СР003426.1 & Rickettsia raoultii \\
\hline $\begin{array}{l}\text { Haemaphysalis } \\
\quad \text { inermis }\end{array}$ & 99 & 99.84 & HM161789.1 & Rickettsia raoultii \\
\hline $\begin{array}{l}\text { Dermacentor } \\
\text { reticulatus }\end{array}$ & 100 & 100 & KX506737.1 & Rickettsia raoultii \\
\hline $\begin{array}{l}\text { Dermacentor } \\
\text { reticulatus }\end{array}$ & 100 & 99.84 & HM161789.1 & Rickettsia raoultii \\
\hline $\begin{array}{l}\text { Haemaphysalis } \\
\quad \text { inermis }\end{array}$ & 100 & 100 & KX506737.1 & Rickettsia raoultii \\
\hline $\begin{array}{l}\text { Dermacentor } \\
\text { reticulatus }\end{array}$ & 99 & 100 & HM161792.1 & Rickettsia raoultii \\
\hline
\end{tabular}

In previously published studies from the Slovak karst area, we confirmed several species of rickettsiae ( $R$. slovaca, R. helvetica, Rickettsia felis, Rickettsia sp.) and Borrelia miyamotoi in small mammals (especially in rodents), from rodent-attached ticks, as well as from questing ticks sampled from vegetation (Radzijevskaja et al. 2015; Heglasová et al. 2018). There is a characteristically high concentration of deer in the area, as well as cattle grazing on the pastures and both vertebrate groups are hosts for adult ticks. These factors increase the significance of the study area from an epidemiological point of view (Černý 1972).

Here, we demonstrated the circulation of $R$. raoultii in the studied area. Although $R$. raoultii has been already detected in $D$. reticulatus and in patients bitten by D. reticulatus (Parola et al. 2009), the vector competence of $D$. marginatus and $H$. inermis to transmit $R$. raoultii cannot be confirmed, because the detection of this bacterium in the latter could be the consequence of a bacterial blood meal of these ticks. Therefore, additional epidemiological studies and experimental models will be needed.

Both Dermacentor and Haemaphysalis ticks from which confirmed positive cases of Rickettsia originate are typical species for forest-steppe zones (D. marginatus, $H$. inermis), alluvial forests and wet meadows, which are commonly seen biotopes in eastern Slovakia (D. reticulatus, H. concinna). The joint occurrence of steppe landscape and xerothermic tick species together with ticks that prefer humid habitats in the studied area is probably caused by the presence of ponds and canals in the karst area as well as by the high density of hosts (birds, small mammals, wild ungulates, cattle) for all life stages of ticks. Dermacentor reticulatus was described as harbouring more bacteria than D. marginatus (Zhang et al. 2019). Rickettsia raoultii is usually associated with Dermacentor spp. (Špitalská et al. 2012; Švehlová et al. 2014). Sequencing partial $о m p B$ genes revealed the presence of $R$. raoultii in the larvae and nymphs of $D$. reticulatus ticks in Germany (Schmuck et al. 2020). In recent decades, the spread of $D$. reticulatus to new territories has been confirmed, having been reported in, for example, in Poland (Kiewra and Czulowska 2013; Mierzejewska et al. 2016), Germany (Dautel et al. 2006) as well as other European countries (Földvári et al. 2016; Kjær et al. 2019; Capligina et al. 2020). One study carried out in Latvia detected the presence of $R$. raoultii in D. reticulatus, their results corroborate with our study. Experimental models will therefore be necessary to understand the role of $D$. reticulatus in the appearance of $R$. raoultii (Capligina et al. 2020).

The indication of $H$. inermis harbouring rickettsiae was noted (̌̌eháček et al. 1976a, b). However, the role of Haemaphysalis spp. as vectors of Rickettsia spp. is unknown (Minichová et al. 2017). There is little data on bacterial associations with $H$. inermis. Rickettsia aeschlimannii was detected in La Rioja, Spain (Portillo et al. 2008). Rickettsia slovaca (Ibarra et al. 2006) and $R$. raoultii are responsible for tick- 
borne lymphadenopathy/ Dermacentor-borne necrosis erythema and lymphadenopathy/scalp eschar and neck lymphadenopathy (TIBOLA/-DEBONEL/SENLAT) (Oteo et al. 2004; Selmi et al. 2008; Parola et al. 2013). This illness commonly occurs in Slovakia (Sekeyová et al. 2013) and was recently identified as the causative agent of tick-borne lymphadenopathy in Belgium (Lernout et al. 2019). Rickettsia helvetica is considered less pathogenic than the two aforementioned rickettsial pathogens (Sprong et al. 2009; Boulanger et al. 2019).

\section{Conclusions}

This molecular study supports the data that $R$. raoultii could be a source of lymphadenopathy in Slovak populations. Further studies, including experimental models, will be needed to assess the role of $D$. reticulatus and $H$. inermis in the transmission of $R$. raoultii. Nevertheless, based on the positive detection of $R$. raoultii, we assume that Haemaphysalis and Dermacentor spp. should be considered as potential reservoirs of $R$. raoultii in Slovakia.

Acknowledgements The authors thank Ladislav Mošanský for his help with tick collection.

Author Contributions ZS, PP and OM conceived and designed the research. BO, BE and ML conducted the experiments. MS, and ZS contributed analytical tools. $\mathrm{BO}$ and $\mathrm{BE}$ analysed the data. $\mathrm{BO}$ and $\mathrm{ZS}$ wrote the manuscript. All authors read and approved the manuscript.

Funding This study was supported by the Institut Hospitalo-Universitaire (IHU) Méditerranée Infection, the French National Research Agency under the "Investissements d'avenir" programme, reference ANR-10IAHU-03, the Région Provence-Alpes-Côte d'Azur and the European funding ERDF PRIMI. Z.S. acknowledges financial support from SRDA-19-0066 and VEGA 2/0010/19, and 2/0021/21, from the Scientific Grant Agency of the Ministry of Education, Science, Research and Sport.

\section{Declarations}

Conflict of interest The authors have no conflicts of interest to disclose.

Open Access This article is licensed under a Creative Commons Attribution 4.0 International License, which permits use, sharing, adaptation, distribution and reproduction in any medium or format, as long as you give appropriate credit to the original author(s) and the source, provide a link to the Creative Commons licence, and indicate if changes were made. The images or other third party material in this article are included in the article's Creative Commons licence, unless indicated otherwise in a credit line to the material. If material is not included in the article's Creative Commons licence and your intended use is not permitted by statutory regulation or exceeds the permitted use, you will need to obtain permission directly from the copyright holder. To view a copy of this licence, visit http://creativecommons.org/licenses/by/4.0/.

\section{References}

Aouadi A, Leulmi H, Boucheikhchoukh M, Benakhla A, Raoult D, Parola P (2017) Molecular evidence of tick-borne hemoprotozoanparasites (Theileria ovis and Babesia ovis) and bacteria in ticks and blood from small ruminants in Northern Algeria. Comp Immunol Microbiol Infect Dis 50:34-39. https://doi.org/10.1016/j.cimid. 2016.11.008

Boldiš V, Kocianová E, Štrus J, Tušek-Žnidarič M, Sparagano OA, Štefanidesová K, Špitalská E (2008) Rickettsial agents in Slovakian ticks (Acarina, Ixodidae) and their ability to grow in Vero and L929 cell lines. Ann N Y Acad Sci 1149:281-285. https://doi.org/10.1196/annals.1428.090

Bona M, Stanko M (2013) First records of the tick Ixodes frontalis (Panzer, 1795) (Acari, Ixodidae) in Slovakia. Ticks Tick Borne Dis 4:478-481. https://doi.org/10.1016/j.ttbdis.2013.06.002

Boulanger N, Boyer P, Talagrand-Reboul E, Hansmann Y (2019) Ticks and tick-borne diseases. Med Mal Infect 49:87-97. https://doi.org/ 10.1016/j.medmal.2019.01.007

Capligina V, Seleznova M, Akopjana S, Freimane L, Lazovska M, Krumins R, Kivrane A, Namina A, Aleinikova D, Kimsis J (2020) Large-scale countrywide screening for tick-borne pathogens in fieldcollected ticks in Latvia during 2017-2019. Parasit Vectors 13:112. https://doi.org/10.1186/s13071-020-04219-7

Černý V (1972) The tick fauna of Czechoslovakia. Folia Parasitol 19:8792

Chvostáč M, Špitalská E, Václav R, Vaculová T, Minichová L, Derdáková M (2018) Seasonal patterns in the prevalence and diversity of tick-borne Borrelia burgdorferi sensu lato, Anaplasma phagocytophilum and Rickettsia spp. in an urban temperate forest in south western Slovakia. Int J Environ Res Publ Health 15:994. https://doi.org/10.3390/ijerph15050994

Dahmani M, Davoust B, Benterki MS, Fenollar F, Raoult D, Mediannikov O (2015a) Development of a new PCR-based assay to detect Anaplasmataceae and the first report of Anaplasma phagocytophilum and Anaplasma platys in cattle from Algeria. Comp Immunol Microbiol Infect Dis 39:39-45. https://doi.org/10. 1016/j.cimid.2015.02.002

Dahmani M, Loudahi A, Mediannikov O, Fenollar F, Raoult D, Davoust B (2015b) Molecular detection of Anaplasma platys and Ehrlichia canis in dogs from Kabylie, Algeria. Ticks Tick Borne Dis 6:198203. https://doi.org/10.1016/j.ttbdis.2014.12.007

Dautel H, Dippel C, Oehme R, Hartelt K, Schettler E (2006) Evidence for an increased geographical distribution of Dermacentor reticulatus in Germany and detection of Rickettsia sp. RpA4. Int J Med Microbiol 296:149-156. https://doi.org/10.1016/j.ijmm.2006.01.013

de la Fuente J, Estrada-Pena A, Venzal JM, Kocan KM, Sonenshine DE (2008) Overview: ticks as vectors of pathogens that cause disease in humans and animals. Front Biosci 13:6938-6946. https://doi.org/10. $2741 / 3200$

Diarra AZ, Almeras L, Laroche M, Berenger J-M, Koné AK, Bocoum Z, Dabo A, Doumbo O, Raoult D. Parola P (2017) Molecular and MALDI-TOF identification of ticks and tick-associated bacteria in Mali. PLoS Negl Trop Dis 11:e0005762. https://doi.org/10.1371/ journal.pntd.0005762

Diarra AZ, Kone AK, Niare SD, Laroche M, Diatta G, Atteynine SA, Coulibaly M, Sangare AK, Kouriba B, Djimde A (2020) Molecular detection of microorganisms associated with small mammals and their ectoparasites in Mali. Am J Trop Med Hyg 103:2542-2551. https://doi.org/10.4269/ajtmh.19-0727

Eldin C, Parola P (2018) Update on tick-borne bacterial diseases in travelers. Curr Infect Dis Rep 20:17. https://doi.org/10.1007/s11908018-0624-y 
Földvári G, Rigó K, Lakos A (2013) Transmission of Rickettsia slovaca and Rickettsia raoultii by male Dermacentor marginatus and Dermacentor reticulatus ticks to humans. Diagn Microbiol Infect Dis 76:387-389. https://doi.org/10.1016/j.diagmicrobio.2013.03. 005

Földvári G, Široký P, Szekeres S, Majoros G, Sprong H (2016) Dermacentor reticulatus: a vector on the rise. Parasit Vectors 9:129. https://doi.org/10.1186/s13071-016-1599-x

Garcia-Vozmediano A, Giglio G, Ramassa E, Nobili F, Rossi L, Tomassone L (2020) Dermacentor marginatus and Dermacentor reticulatus, and their infection by SFG Rickettsiae and Francisella-Like Endosymbionts, in mountain and periurban habitats of Northwestern Italy. Vet Sci 7:157. https://doi.org/10.3390/ vetsci7040157

Heglasová I, Víchová B, Kraljik J, Mošanský L, Miklisová D, Stanko M (2018) Molecular evidence and diversity of the spotted-fever group Rickettsia spp. in small mammals from natural, suburban and urban areas of Eastern Slovakia. Ticks Tick Borne Dis 9:1400-1406. https://doi.org/10.1016/j.ttbdis.2018.06.011

Heglasová I, Rudenko N, Golovchenko M, Zubriková D, Miklisová D, Stanko M (2020) Ticks, fleas and rodent-hosts analyzed for the presence of Borrelia miyamotoi in Slovakia: the first record of Borrelia miyamotoi in a Haemaphysalis inermis tick. Ticks Tick Borne Dis 11:101456. https://doi.org/10.1016/j.ttbdis.2020.101456

Hornok S, Meli ML, Perreten A, Farkas R, Willi B, Beugnet F, Lutz H, Hofmann-Lehmann R (2010) Molecular investigation of hard ticks (Acari: Ixodidae) and fleas (Siphonaptera: Pulicidae) as potential vectors of rickettsial and mycoplasmal agents. Vet Microbiol 140: 98-104. https://doi.org/10.1016/j.vetmic.2009.07.013

Ibarra V, Oteo J, Portillo A, Santibanez S, Blanco J, Metola L, Eiros Bouza JM, Pérez Martínez L, Sanz M (2006) Rickettsia slovaca infection: DEBONEL/TIBOLA. Ann N Y Acad Sci 1078:206214. https://doi.org/10.1196/annals. 1374.040

Kiewra D, Czulowska A (2013) Evidence for an increased distribution range of Dermacentor reticulatus in south-west Poland. Exp Appl Acarol 59:501-506. https://doi.org/10.1007/s10493-012-9612-3

Kjær LJ, Soleng A, Edgar KS, Lindstedt HEH, Paulsen KM, Andreassen ÅK, Korslund L, Kjelland V, Slettan A, Stuen S (2019) A largescale screening for the taiga tick, Ixodes persulcatus, and the meadow tick, Dermacentor reticulatus, in southern Scandinavia, 2016. Parasit Vectors 12:338. https://doi.org/10.1186/s13071-019-3596-3

Lernout T, De Regge N, Tersago K, Fonville M, Suin V, Sprong H (2019) Prevalence of pathogens in ticks collected from humans through citizen science in Belgium. Parasit Vectors 12:550. https://doi.org/ 10.1186/s13071-019-3806-Z

Mierzejewska EJ, Estrada-Peña A, Alsarraf M, Kowalec M, Bajer A (2016) Mapping of Dermacentor reticulatus expansion in Poland in 2012-2014. Ticks Tick Borne Dis 7:94-106. https://doi.org/10. 1016/j.ttbdis.2015.09.003

Minichová L, Hamšíková Z, Mahríková L, Slovák M, Kocianová E, Kazimírová M, Škultéty L, Štefanidesová K, Špitalská E (2017) Molecular evidence of Rickettsia spp. in ixodid ticks and rodents in suburban, natural and rural habitats in Slovakia. Parasit Vectors 10:158. https://doi.org/10.1186/s13071-017-2094-8

Nosek J (1971) The ecology, bionomics, and behaviour of Haemaphysalis (Aboimisalis) punctata tick in central Europe. Ztschr Parasitenk 37:198-210. https://doi.org/10.1007/ BF00259499

Nosek J (1972) The ecology and public health importance of Dermacentor marginatus and D. reticulatus ticks in central Europe. Folia Parasitol 19:93-102

Nosek J (1973) Some characteristic features of the life history, ecology and behaviour of the ticks Haemaphysalis inermis, H. concinna and H. punctata. In: Daniel M, Rosický B (eds) Proceedings of the 3rd International Congress of Acarology, Springer, Dordrecht, pp 479482. https://doi.org/10.1007/978-94-010-2709-0_90
Oteo J, Ibarra V, Blanco J, de Artola VM, Márquez F, Portillo A, Raoult D, Anda P (2004) Dermacentor-borne necrosis erythema and lymphadenopathy: clinical and epidemiological features of a new tick-borne disease. Clin Microbiol Infect 10:327-331. https://doi. org/10.1111/j.1198-743X.2004.00782.x

Ouarti B, Mediannikov O, Righi S, Benakhla A, Raoult D, Parola P (2020) Molecular detection of microorganisms in lice collected from farm animals in Northeastern Algeria. Comp Immunol Microbiol Infect Dis 74:101569-101569. https://doi.org/10.1016/j.cimid. 2020.101569

Parola P, Rovery C, Rolain JM, Brouqui P, Davoust B, Raoult D (2009) Rickettsia slovaca and $R$. raoultii in tick-borne rickettsioses. Emerg Infect Dis 15:1105. https://doi.org/10.3201/eid1507.081449

Parola P, Paddock CD, Socolovschi C, Labruna MB, Mediannikov O, Kernif T, Abdad MY, Stenos J, Bitam I, Fournier P-E (2013) Update on tick-borne rickettsioses around the world: a geographic approach. Clin Microbiol Rev 26:657-702. https://doi.org/10.1128/CMR. 00032-13

Portillo A, Santibáñez P, Santibáñez S, Pérez-Martínez L, Oteo JA (2008) Detection of Rickettsia spp. in Haemaphysalis ticks collected in La Rioja, Spain. Vector Borne Zoonotic Dis 8:653-658. https://doi.org/ 10.1089/vbz.2007.0272

Radzijevskaja J, Paulauskas A, Aleksandraviciene A, Jonauskaite I, Stanko M, Karbowiak G, Petko B (2015) New records of spotted fever group rickettsiae in Baltic region. Microbes Infect 17:874 878. https://doi.org/10.1016/j.micinf.2015.09.006

Řeháček J, Kováčová E, Kováč P (1976a) Rickettsiae belonging to the spotted fever group from ticks in the Tribeč mountains. Folia Parasitol 23:69-73

Řeháček J, Župančičová M, Áč P, Brezina R, Úrvölgyi J, Kováčová E, Tarasevič I, Jablonskaja V, Pospíšil R, Baloghova D (1976b) Rickettsioses studies: 2. Natural foci of rickettsioses in east Slovakia. Bull World Health Org 53:31-38

Schmuck HM, Chitimia-Dobler L, Król N, Kacza J, Pfeffer M (2020) Collection of immature Dermacentor reticulatus (Fabricius, 1794) ticks from vegetation and detection of Rickettsia raoultii in them. Ticks Tick Borne Dis 11:101543. https://doi.org/10.1016/j.ttbdis. 2020.101543

Sekeyova Z, Roux V, Xu W, Řeháček J, Raoult D (1998) Note: Rickettsia slovaca sp. nov., a member of the spotted fever group rickettsiae. Int J Syst Evol Microbiol 48:1455-1462. https://doi.org/10.1099/ 00207713-48-4-1455

Sekeyová Z, Socolovschi C, Špitalská E, Kocianová E, Boldiš V, Quevedo Diaz M, Berthová L, Bohácsová M, Valáriková J, Fournier PE (2013) Update on rickettsioses in Slovakia. Acta Virol 57:180-199. https://doi.org/10.4149/av_2013_02_180

Selmi M, Bertolotti L, Tomassone L, Mannelli A (2008) Rickettsia slovaca in Dermacentor marginatus and tick-borne lymphadenopathy Tuscany, Italy. Emerg Infect Dis 14:817. https://doi.org/10. 3201/eid1405.070976

Socolovschi C, Kernif T, Raoult D, Parola P (2012a) Borrelia, Rickettsia, and Ehrlichia species in bat ticks, France, 2010. Emerg Infect Dis 18:1966-1975. https://doi.org/10.3201/eid1812.111237

Socolovschi C, Pagés F, Raoult D (2012b) Rickettsia felis in Aedes albopictus mosquitoes, Libreville, Gabon. Emerg Infect Dis 18: 1687-1689. https://doi.org/10.3201/eid1810.120178

Špitalská E, Štefanidesová K, Kocianová E, Boldiš V (2012) Rickettsia slovaca and Rickettsia raoultii in Dermacentor marginatus and Dermacentor reticulatus ticks from Slovak Republic. Exp Appl Acarol 57:189-197. https://doi.org/10.1007/s10493-012-9539-8

Špitalská E, Sparagano O, Stanko M, Schwarzová K, Špitalský Z, Škultéty L, Fumačová Havlíková S (2018) Diversity of Coxiellalike and Francisella-like endosymbionts, and Rickettsia spp., Coxiella burnetii as pathogens in the tick populations of Slovakia. Central Europe. Ticks Tick Borne Dis 9:1207-1211. https://doi.org/ 10.1016/j.ttbdis.2018.05.002 
Sprong H, Wielinga PR, Fonville M, Reusken C, Brandenburg AH, Borgsteede F, Gaasenbeek C, van der Giessen JW (2009) Ixodes ricinus ticks are reservoir hosts for Rickettsia helvetica and potentially carry flea-borne Rickettsia species. Parasit Vectors 2:41. https://doi.org/10.1186/1756-3305-2-41

Švehlová A, Berthová L, Sallay B, Boldiš V, Sparagano OA, Špitalská E (2014) Sympatric occurrence of Ixodes ricinus, Dermacentor reticulatus and Haemaphysalis concinna ticks and Rickettsia and Babesia species in Slovakia. Ticks Tick Borne Dis 5:600-605. https://doi.org/10.1016/j.ttbdis.2014.04.010
Zhang YK, Yu ZJ, Wang D, Víchová B, Pet'ko B, Liu JZ (2019) The bacterial microbiome of field-collected Dermacentor marginatus and Dermacentor reticulatus from Slovakia. Parasit Vectors 12: 325. https://doi.org/10.1186/s13071-019-3582-9

Publisher's Note Springer Nature remains neutral with regard to jurisdictional claims in published maps and institutional affiliations. 